\title{
Removal of Actacid Orange-RL Dye Using Biocomposites: Modeling Studies
}

\author{
Saima Noreen ${ }^{1}$, Haq Nawaz Bhatti ${ }^{1 *}$, Mohammad Zuber ${ }^{2}$, \\ Muhammad Zahid', Muhammad Asgher ${ }^{3}$ \\ 'Environmental and Material Chemistry Laboratory, Department of Chemistry, University of Agriculture, \\ Faisalabad 38040, Pakistan \\ ${ }^{2}$ Department of Applied Chemistry, Govt College University, Faisalabad, Pakistan \\ ${ }^{3}$ Department of Biochemistry, University of Agriculture, Faisalabad 38040, Pakistan
}

Received: 25 November 2016

Accepted: 12 January 2017

\begin{abstract}
Textile industry wastewater plays an important role in environmental pollution. In the present study, the removal of actacid orange-RL (AO-RL) dye was carried out in batch mode with biocomposites. The optimum $\mathrm{pH}$, biosorbent dose, equilibrium time, initial dye concentration, and temperature for maximum dye adsorption were recorded in the range of 3-6, $0.05 \mathrm{~g}, 60 \mathrm{~min}$ and $125-150 \mathrm{mg} / \mathrm{L}$ and $30^{\circ} \mathrm{C}$, respectively. Langmuir and Freundlich biosorption isotherms showed the satisfactorily fitness on equilibrium biosorption data, whereas the pseudo first-order and pseudo second-order both showed the satisfactorily fitness on biosorption kinetic data. The characterization of efficient biosorbents was carried out using FT-IR and SEM techniques, which revealed a significant change in biocomposite as a result of dye adsorption. Based on results, we can conclude that the biocomposite could be an efficient adsorbent for the adsorption of dyes from textile wastewater.
\end{abstract}

Keywords: biosorption, acid dye, biocomposite, batch study, characterization

\section{Introduction}

Environmental pollution, particularly water pollution, is increasing day by day due to rapid industrialization. Various industries such as plastics, textiles, paper, leather, rubber, cosmetics, and pharmaceuticals generally use different dyes to color their products. The textile sector significantly contributes to water pollution due to the discharge of a huge volume of effluent containing

*e-mail: hnbhatti2005@yahoo.com,haq_nawaz@uaf.edu.pk inorganic salts, alkalis, surfactants, and organic matter like dyes [1-4].

Recently, biosorbents based on biomaterials have received much interest due to their efficiency and environmentally friendly nature for adsorbing dyes from textile wastewater [5-8]. The interest has grown for the use of non-conventional, less expensive adsorbents like natural materials. Different agro wastes such as rice husks, cotton waste, canola hulls, citrus biomass, peanut hulls, [9], sugarcane bagasse, and sugar beets can be used as good adsorbents [10]. Yet, it has been observed that biomaterials 
do not show very high biosorption performance in their natural form or without any modification [11]. The efficiency of these adsorbents can be enhanced by making composites.

Composite adsorbents are those adsorbents that are produced by using two or more materials. Composite adsorbents boost the efficacy of the adsorption process to such an extent that it cannot be attained with the help of a single adsorbent. Nowadays, attention is given to the development of biocomposites. Biocomposites are those composite materials in which at least one main constituent is obtained from biological material. Biological materials mostly consist of lignocellulosic residues like natural fibers, which are regarded as eco-friendly substances for the formation of biocomposites [12-13]. The present study was comprised of a simple and efficient method for the removal of synthetic dyes from aqueous media using biocomposites in batch mode. It was cost-effective because cheap chemicals and locally existing resources were needed, and high-cost treatment plants and techniques were not required.

\section{Materials and Methods}

The $5.0 \mathrm{~g}$ of freshly distilled aniline were dissolved in $250 \mathrm{~mL}$ of $1 \mathrm{M} \mathrm{HCl}$. The mixture cooled to below $5^{\circ} \mathrm{C}$ using an ice bath. $250 \mathrm{~mL}$ of a pre-cooled $0.3 \mathrm{M}$ ammonium peroxydisulfate $\left(\mathrm{NH}_{4} \mathrm{~S}_{2} \mathrm{O}_{8}\right)$ solution in $1 \mathrm{M} \mathrm{HCl}$ was slowly added under vigorous stirring to monomer the solution over a period of $30 \mathrm{~min}$. In order to make polyaniline soluble in formic acid for composite formation, the polymer was treated with $0.5 \mathrm{M} \mathrm{NaOH}$ solution for two hours. Then it was washed with distilled water and dried in an oven at $60^{\circ} \mathrm{C}$. $0.50 \mathrm{~g}$ of a base-treated PAn was dissolved in $50 \mathrm{~mL}$ of formic acid. For preparation of polyaniline/Agro waste composite, $5 \mathrm{~g}$ agro waste was mixed with $50 \mathrm{~mL}$ of basetreated PAn in formic acid $(1 \% \mathrm{w} / \mathrm{v})$ in a beaker $\left(100 \mathrm{~cm}^{3}\right)$ and stirred for $2 \mathrm{~h}$ at room temperature and left for another $2 \mathrm{~h}$ without stirring [14]. After drying and grinding, it was sieved up to $300 \mu \mathrm{m}$ mesh size and stored in airtight jars for further study.

The poly pyrrole/agro waste (PPy/agro waste) composites were synthesized by soaking the agro wastes in monomer pyrrole solution $(0.2 \mathrm{M})$ for $12 \mathrm{~h}$ at room temperature followed by the slow addition of chemical oxidants $0.5 \mathrm{M} \mathrm{FeCl}_{3}$ at room temperature for $4 \mathrm{~h}$. The PPy/agro waste composites were filtered and then washed with distilled water [16].

$1 \mathrm{~g}$ of chitosan was dissolved in aqueous acetic acid $(20 \%)$, and the solution was stirred for $24 \mathrm{~h}$ at room temperature. To this, about $0.01 \mathrm{M}$ of aniline dissolved in $1 \mathrm{M} \mathrm{HCl}$ was added and stirred for $15 \mathrm{~min}$ to form a homogenous solution. $4.4 \mathrm{~g}$ of ammonium peroxydisulfate $\left(\mathrm{NH}_{4} \mathrm{~S}_{2} \mathrm{O}_{8}\right)$ solution in $1 \mathrm{M} \mathrm{HCl}$ was dropped into the above solution with constant stirring at $5^{\circ} \mathrm{C}$ [16].

Polypyrrole/Chitosan composite (PPy/Ch) was prepared by the method adopted for the preparation of $\mathrm{PAn} / \mathrm{Ch}$ composite as described above, with $7.18 \mathrm{~g}$ of ferric chloride (dissolved in minimum amount of methanol) as the oxidizing agent [17].

For synthesis of polyaniline/starch (PAn/St) composite, $4 \%(\mathrm{w} / \mathrm{v})$ starch was suspended in distilled water and the solution was stirred to form a homogenous solution. To this, about $0.01 \mathrm{M}$ aniline dissolved in $1 \mathrm{M} \mathrm{HCl}$ was added drop wise and stirred for $15 \mathrm{~min} .4 .4 \mathrm{~g}$ of ammonium peroxydisulfate $\left(\mathrm{NH}_{4} \mathrm{~S}_{2} \mathrm{O}_{8}\right)$ solution in $1 \mathrm{M} \mathrm{HCl}$ was added drop wise with constant stirring at $5^{\circ} \mathrm{C}$.

Polypyrrole/St (PPy/St) composite was prepared by the method adopted for the preparation of $\mathrm{PAn} / \mathrm{St}$ composite as described above, with $4.4 \mathrm{~g}$ of ferric chloride (dissolved in minimum amount of methanol) as the oxidizing agent [18]. All above biocomposites were synthesized using the 1:3 mass ratios for doing this study.

Batch experiments were conducted to compare the biosorption capacities of biosorbents in native and biocomposite form. Optimization of important process parameters such as $\mathrm{pH}$, contact time, biosorbent dose, initial dye concentration, and temperature for the removal AO-RL dye was carried out using the classical approach. Equilibrium biosorption uptake, $\mathrm{q}_{\mathrm{e}}(\mathrm{mg} / \mathrm{g})$, was calculated using the relationship shown in Eq. 1.

$$
q_{e}=\frac{\left(C_{o}-C_{e}\right) V}{W}
$$

... where $\mathrm{C}_{\mathrm{o}}$ is the initial dye concentration $(\mathrm{mg} / \mathrm{L}), \mathrm{C}_{\mathrm{e}}$ is the equilibrium dye concentration $(\mathrm{mg} / \mathrm{L}), \mathrm{V}$ is the volume of the solution (L), and $\mathrm{w}$ is the mass of the biosorbent $(\mathrm{g})$.

\section{Results and Discussion}

\section{Effect of Process Variables on Adsorption}

$\mathrm{pH}$ is used to measure the acidity or basicity of an aqueous media. $\mathrm{pH}$ acts as the key process parameter in the biosorption process particularly for dye biosorption. $\mathrm{pH}$ controls the extent of electrostatic charges on sorbent and sorbate. Solution $\mathrm{pH}$ effect on biosorption process of acid dye using different biocomposites was investigated by vayring the $\mathrm{pH}$ from 2-11 of the sorbent-sorbate solution containing $0.1 \mathrm{~g} / 50 \mathrm{~mL}$ biosorbent dose and $50 \mathrm{mg} / \mathrm{L}$ initial dye concentration with shaking at $120 \mathrm{rpm}$ and $30^{\circ} \mathrm{C}$ until equilibrium. The results are shown in Fig. 1a). The results show that the optimum $\mathrm{pH}$ values for achieving maximum biosorption capacity of RH (7.3 mg/g), PPy/RH (32.4 mg/g), PAn/RH (30.3 mg/g), PPy/Ch (23.09 mg/g), PAn/Ch (21.4 mg/g), PPy/St $(13.3 \mathrm{mg} / \mathrm{g})$, and PAn/St $(11.4 \mathrm{mg} / \mathrm{g})$ for AO-RL were found to be $3,3,4,5,6,4$, and 4 , respectively. The optimum solution $\mathrm{pH}$ values for getting maximum removal of acid dye were determined in an acidic environment. The reduction in biosorption capacity of all biosorbents for acid dye was seen with the increase of $\mathrm{pH}$ or in alkaline conditions. The reason might be the production of a more positive charge on biosorbent surface because 
of protonation of surface polar functional groups in acidic environment, which showed the high electrostatic attraction with the acid dye anions [19]. The lowering of biosorption capacity of biosorbents under basic conditions or with the elevation of $\mathrm{pH}$ might be due to deprotonation of surface binding functional groups that showed electrostatic repulsion with dye anions, and the high concentration of $\mathrm{OH}^{-}$ions also caused competition with dye anions for binding functional sites [20]. The utilization of polyaniline-coated sawdust for the elimination of acid dye from colored solution was checked. It was inferred that maximum dye removal was achieved below $\mathrm{pH} 5$ and reduction in dye removal was observed by increasing the $\mathrm{pH}$ above 5. It has been observed that the highest reactive dye removal was achieved at $\mathrm{pH} 3-4$ in the acidic range while it was declined with the increment in $\mathrm{pH}$ [21].

The effect of biosorbent dose ( 0.05 to $0.30 \mathrm{~g} / 50 \mathrm{~mL})$ of different biocomposites on biosorption of acid dye was studied under constant operating conditions of optimum $\mathrm{pH}, 50 \mathrm{mg} / \mathrm{L}$ dye concentration, $30^{\circ} \mathrm{C}$ temperature, and $120 \mathrm{rpm}$ shaking until equilibrium. The results are shown in Fig. 1b), and indicate that the biosorption capacity of biosorbents (RH, PPy/RH, PAn/RH, PPy/Ch, PAn/Ch, $\mathrm{PPy} / \mathrm{St}$, and PAn $/ \mathrm{St}$ ) decreased from 11.05 to $1.5 \mathrm{mg} / \mathrm{g}$,
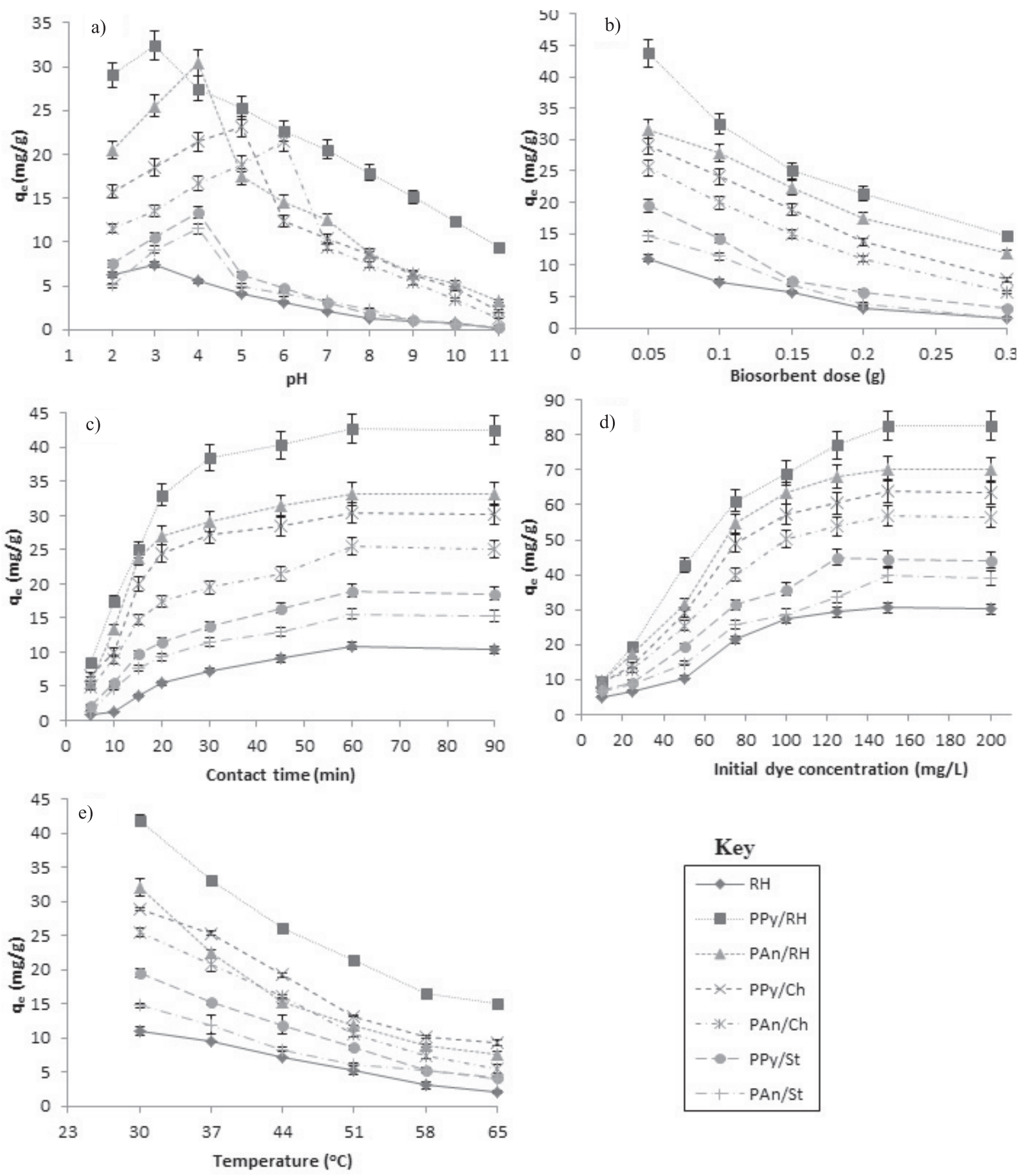

Fig. 1. Effect of process variables on dye adsorption onto biocomposites. 
43.8 to $14.7 \mathrm{mg} / \mathrm{g}, 31.6$ to $11.8 \mathrm{mg} / \mathrm{g}, 29.1$ to $7.7 \mathrm{mg} / \mathrm{g}, 25.4$ to $5.7,19.4$ to 3.13 , and 14.6 to $1.59 \mathrm{mg} / \mathrm{g}$, respectively, by the addition of more doses from 0.05 to $0.30 \mathrm{~g} / 50 \mathrm{~mL}$ in dye solution. The highest biosorption of AO-RL was observed using $0.05 \mathrm{~g} / 50 \mathrm{~mL}$ biosorbent dose. Thus, a $0.05 \mathrm{~g} / 50 \mathrm{~mL}$ dose of all biosorbents was considered their optimum dose to get the maximum removal of dye. From the above results, the decline in biosorption of acid dye was observed by the addition of more biosorbent doses. The highest biosorption of acid dye was observed at the lowest $0.05 \mathrm{~g} / 50 \mathrm{~mL}$ dose of all biosorbents. Such a decline in biosorption capacity of biosorbents at their higher doses might be because of overlapping of binding surface active sites, which caused a reduction in total available surface area for the binding of dye anions and also enlarged the path length of diffusion [22]. Ahmad et al. [23] reported the reduction in biosorption capacity of nanopolyaniline for acid red 14 dye by increasing the biosorbent dose from 0.025 to $0.2 \mathrm{~g}$.

The effect of contact period of sorbate and sorbent on the removal of selected acid dyes using different biosorbents was investigated at different contact times in the range of 5-90 min and results, shown in Fig. 1c), reveal that the biosorption of AO-RL dye was rapid in the initial $20 \mathrm{~min}$, after which it started to slow gradually and then equilibrium was established until $60 \mathrm{~min}$. After equilibrium, there was not any prominent effect of contact period observed on the biosorption of AO-RL using different biosorbents. The maximum biosorption capacity values $(10.9,42.8,33.2,30.3,25.4,18.9$, and $15.5 \mathrm{mg} / \mathrm{g})$ of different biosorbents (RH, PPy/RH, PAn/RH, PPy/Ch, $\mathrm{PAn} / \mathrm{Ch}, \mathrm{PPy} / \mathrm{St}$, and $\mathrm{PAn} / \mathrm{St}$ ) were achieved at equilibrium contact time. The reason behind such biosorption behavior of acid dye using different biosorbents might be due to the availability of higher active functional binding sites on biosorbent surface in the initial stage of the biosorption process, which became engaged by sorbate with the progress of time and then sorbate started to enter slowly inside the biosorbent bulk, which caused the slow biosorption rates at later stages [25]. Tayebi [26] checked the effect of contact time on the removal of reactive orange 16 dye from aqueous media by polyaniline and its nano composite. It was investigated that the rate of biosorption process was rapid until $100 \mathrm{~min}$, and after 150 min equilibrium was established [27].

A batch biosorption experiments was conducted to determine the effects of different initial dye concentrations in the range of $10-200 \mathrm{mg} / \mathrm{L}$ on the biosorption capacities of different biosorbents for acid dye. The results are depicted in Fig. 1d). The maximum biosorption capacities of $\mathrm{RH}, \mathrm{PPy} / \mathrm{RH}, \mathrm{PAn} / \mathrm{RH}, \mathrm{PPy} / \mathrm{Ch}, \mathrm{PAn} / \mathrm{Ch}$, and $\mathrm{PAn} / \mathrm{St}$ for $\mathrm{AO}-\mathrm{RL}$ at $150 \mathrm{mg} / \mathrm{L}$ initial dye concentration were determined to be $30.5,82.8,70.2,63.9,56.7$, and $39.9 \mathrm{mg} / \mathrm{g}$, respectively. The maximum biosorption capacity $(44.9 \mathrm{mg} / \mathrm{g}$ ) of PPy/St for AO-RL was found at $125 \mathrm{mg} / \mathrm{L}$ dye concentration. The reason behind such a trend might be the providing of significant driving force by initial dye concentration to reduce the mass transfer resistance among the solid and aqueous phases [28], and equilibrium was attained due to the establishment of dynamic balance among biosorbent surface and dye concentration. Esmaeli et al. [29] investigated the effect of initial dye concentration in the range of $10-50 \mathrm{mg} / \mathrm{L}$ on the biosorption capacity of brown algae for the acid dyes at $\mathrm{pH} 2$ using the $1 \mathrm{~g} / \mathrm{L}$ biosorbent dose. The biosorption potential for acid dye was enhanced from

Table 1. Kinetic modeling of data for the removal of AO-RL dye using biocomposites.

\begin{tabular}{|c|c|c|c|c|c|c|c|}
\hline \multirow{2}{*}{ Kinetic models } & \multicolumn{7}{|c|}{$\mathrm{AO}-\mathrm{RL}$} \\
\hline & RH & $\mathrm{PPy} / \mathrm{RH}$ & $\mathrm{PAn} / \mathrm{RH}$ & $\mathrm{PPy} / \mathrm{Ch}$ & $\mathrm{PAn} / \mathrm{Ch}$ & $\mathrm{PPy} / \mathrm{St}$ & $\mathrm{PAn} / \mathrm{St}$ \\
\hline \multicolumn{8}{|c|}{ Pseudo first-order } \\
\hline $\mathrm{k}_{1}(\mathrm{~L} / \mathrm{min})$ & 0.03 & 0.05 & 0.06 & 0.05 & 0.04 & 0.04 & 0.04 \\
\hline$q_{e} \exp (m g / g)$ & 10.9 & 42.8 & 33.2 & 30.3 & 25.4 & 18.9 & 15.5 \\
\hline $\mathrm{q}_{\mathrm{e}} \mathrm{cal}(\mathrm{mg} / \mathrm{g})$ & 11.8 & 38.9 & 30.2 & 23.3 & 24.04 & 19.3 & 16.9 \\
\hline $\mathrm{R}^{2}$ & 0.979 & 0.987 & 0.981 & 0.966 & 0.977 & 0.990 & 0.996 \\
\hline \multicolumn{8}{|c|}{ Pseudo second-order } \\
\hline $\mathrm{k}_{2}(\mathrm{~g} / \mathrm{mg} \min )$ & $1.30 \times 10^{-4}$ & $9.81 \times 10^{-4}$ & $1.21 \times 10^{-3}$ & $1.45 \times 10^{-3}$ & $1.30 \times 10^{-3}$ & $8.46 \times 10^{-4}$ & $7.02 \times 10^{-4}$ \\
\hline $\mathrm{q}_{\mathrm{e}} \exp (\mathrm{mg} / \mathrm{g})$ & 10.9 & 42.8 & 33.2 & 30.3 & 25.4 & 18.9 & 15.5 \\
\hline $\mathrm{q}_{\mathrm{e}} \mathrm{cal}(\mathrm{mg} / \mathrm{g})$ & 40 & 55.5 & 43.4 & 38.4 & 33.3 & 29.4 & 27.02 \\
\hline $\mathrm{R}^{2}$ & 0.147 & 0.969 & 0.935 & 0.955 & 0.972 & 0.860 & 0.683 \\
\hline \multicolumn{8}{|c|}{ Intraparticle diffusion } \\
\hline $\mathrm{K}_{\mathrm{pi}}\left(\mathrm{mg} / \mathrm{g} \cdot \min ^{1 / 2}\right)$ & 1.53 & 4.66 & 3.52 & 3.27 & 2.82 & 2.34 & 1.95 \\
\hline $\mathrm{C}_{\mathrm{i}}$ & -2.175 & 5.871 & 5.561 & 4.500 & 1.934 & -0.586 & -0.795 \\
\hline $\mathrm{R}^{2}$ & 0.905 & 0.801 & 0.737 & 0.761 & 0.873 & 0.892 & 0.897 \\
\hline
\end{tabular}


$7.2-23.3 \mathrm{mg} / \mathrm{g}$ by raising the dye concentration of solution from $10-50 \mathrm{mg} / \mathrm{L}$ [30].

The effect of different process temperatures in the range of $30-65^{\circ} \mathrm{C}$ on the biosorption capacities of different selected biosorbents for the removal of acid dye from aqueous solution was checked on fixed experimental operating conditions. The results are indicated in Fig. 1e). The highest biosorption efficiency of all biosorbents was achieved at $30^{\circ} \mathrm{C}$ for the removal of acid dye. The reduction in acid dye biosorption at higher values of temperature might be because of a breakdown of sorption forces that were responsible for the biosorption of molecules of dye on the biosorbent surface [30]. Akar et al. [31] observed the significant effect of enhancing temperature from $20-40^{\circ} \mathrm{C}$ on the removal of acid blue 40 dye using the Thujaorientalis cone. The maximum removal of acid dye was achieved at lower temperature and reduction in removal was observed as the solution temperature was enhanced [32].

\section{Kinetic Studies}

The linear integrated equation of the pseudo first-order kinetic model is [33]:

$$
\log \left(q_{e}-q_{t}\right)=\log q_{e}-k_{1} \cdot \frac{\mathrm{t}}{2.303}
$$

The linear equation of the pseudo second-order is:

$$
\left(\frac{t}{q_{t}}\right)=\frac{1}{k_{2} q e^{2}}+\frac{t}{q e}
$$

\begin{tabular}{|c|c|c|c|c|c|c|c|}
\hline \multirow{2}{*}{ Isotherm models } & \multicolumn{7}{|c|}{ AO-RL } \\
\hline & RH & $\mathrm{PPy} / \mathrm{RH}$ & $\mathrm{PAn} / \mathrm{RH}$ & $\mathrm{PPy} / \mathrm{Ch}$ & $\mathrm{PAn} / \mathrm{Ch}$ & $\mathrm{PPy} / \mathrm{St}$ & $\mathrm{PAn} / \mathrm{St}$ \\
\hline \multicolumn{8}{|c|}{ Langmuir } \\
\hline $\mathrm{q}_{\mathrm{m}} \mathrm{Cal}(\mathrm{mg} / \mathrm{g})$ & 50 & 90.90 & 83.3 & 76.9 & 71.4 & 62.5 & 58.8 \\
\hline $\mathrm{q}_{\mathrm{m}} \operatorname{Exp}(\mathrm{mg} / \mathrm{g})$ & 30.5 & 82.8 & 70.2 & 63.9 & 56.7 & 44.9 & 39.9 \\
\hline $\mathrm{b}$ & 0.01 & 0.11 & 0.06 & 0.04 & 0.03 & 0.01 & 0.01 \\
\hline $\mathrm{R}_{\mathrm{L}}$ & 0.36 & 0.05 & 0.09 & 0.13 & 0.16 & 0.29 & 0.31 \\
\hline $\mathrm{R}^{2}$ & 0.709 & 0.984 & 0.959 & 0.919 & 0.901 & 0.844 & 0.823 \\
\hline \multicolumn{8}{|c|}{ Freundlich } \\
\hline $\mathrm{q}_{\mathrm{m}} \mathrm{Cal}(\mathrm{mg} / \mathrm{g})$ & 28.70 & 82.7 & 69.01 & 61.6 & 50.2 & 36.3 & 34.08 \\
\hline $\mathrm{K}_{\mathrm{F}}$ & 1.56 & 15.7 & 11.6 & 8.29 & 9.68 & 3.17 & 2.64 \\
\hline $\mathrm{n}$ & 1.64 & 2.53 & 2.45 & 2.22 & 2.75 & 1.79 & 1.83 \\
\hline $\mathrm{R}^{2}$ & 0.886 & 0.902 & 0.895 & 0.870 & 0.830 & 0.900 & 0.916 \\
\hline \multicolumn{8}{|c|}{ Temkin } \\
\hline $\mathrm{q}_{\mathrm{m}} \mathrm{Cal}(\mathrm{mg} / \mathrm{g})$ & 28.1 & 77.1 & 65.5 & 55.8 & 50.1 & 37.8 & 33.8 \\
\hline A & 0.20 & 3.55 & 2.13 & 1.12 & 2.04 & 0.33 & 0.28 \\
\hline B & 8.75 & 14.1 & 12.7 & 12.9 & 9.54 & 11.48 & 9.81 \\
\hline $\mathrm{R}^{2}$ & 0.829 & 0.879 & 0.813 & 0.809 & 0.75 & 0.847 & 0.841 \\
\hline \multicolumn{8}{|c|}{ Harkins-Jura } \\
\hline $\mathrm{q}_{\mathrm{m}} \mathrm{Cal}(\mathrm{mg} / \mathrm{g})$ & 3.0 & 9.3 & 8. & 7.1 & 7.6 & 4.6 & 4.06 \\
\hline A & 37.03 & 333.3 & 250 & 200 & 250 & 83.3 & 66.6 \\
\hline B & 2.03 & 2 & 2 & 2 & 2.25 & 2 & 2 \\
\hline $\mathrm{R}^{2}$ & 0.916 & 0.796 & 0.880 & 0.885 & 0.913 & 0.889 & 0.926 \\
\hline \multicolumn{8}{|c|}{ Doubinin-Radushkevich } \\
\hline $\mathrm{q}_{\mathrm{m}} \mathrm{Cal}(\mathrm{mg} / \mathrm{g})$ & 20.2 & 57.05 & 48.8 & 43.5 & 38.01 & 29.8 & 24.7 \\
\hline$\beta\left(\mathrm{mol}^{2} \mathrm{~kJ}{ }^{-2}\right)$ & $7 \times 10^{-6}$ & $1 \times 10^{-7}$ & $2 \times 10^{-7}$ & $4 \times 10^{-7}$ & $2 \times 10^{-7}$ & $3 \times 10^{-6}$ & $3 \times 10^{-6}$ \\
\hline $\mathrm{E}\left(\mathrm{kJmol}^{-1}\right)$ & 0.26 & 2.23 & 1.58 & 1.11 & 1.58 & 0.40 & 0.40 \\
\hline $\mathrm{R}^{2}$ & 0.478 & 0.636 & 0.587 & 0.539 & 0.478 & 0.503 & 0.481 \\
\hline
\end{tabular}

Table 2. Equilibrium modeling of data for the removal of AO-RL. 
Table 3. Thermodynamic parameters for the removal of AO-RL dye.

\begin{tabular}{|c|c|c|c|c|c|c|}
\hline \multirow{2}{*}{ Thermodynamic parameters } & \multicolumn{6}{|c|}{$\mathrm{AO}-\mathrm{RL}$} \\
\hline & 303 & 310 & 317 & 324 & 331 & 338 \\
\hline \multicolumn{7}{|c|}{ RH } \\
\hline$\Delta \mathrm{G}^{\circ}(\mathrm{kJ} / \mathrm{mol})$ & -3.18 & -3.73 & -4.70 & -5.73 & -7.47 & -8.84 \\
\hline$\Delta \mathrm{H}^{\circ}(\mathrm{kJ} / \mathrm{mol})$ & -46.82 & & & & & \\
\hline$\Delta \mathrm{S}^{\circ}\left(\mathrm{Jmol}^{-1} \mathrm{~K}^{-1}\right)$ & -163.61 & & & & & \\
\hline \multicolumn{7}{|c|}{ PPy/RH } \\
\hline$\Delta \mathrm{G}^{\circ}(\mathrm{kJ} / \mathrm{mol})$ & -4.15 & -1.72 & -0.23 & -0.74 & -1.94 & -2.34 \\
\hline$\Delta \mathrm{H}^{\circ}(\mathrm{kJ} / \mathrm{mol})$ & -59.30 & & & & & \\
\hline$\Delta \mathrm{S}^{\circ}\left(\mathrm{Jmol}^{-1} \mathrm{~K}^{-1}\right)$ & -184.48 & & & & & \\
\hline \multicolumn{7}{|c|}{ PAn/RH } \\
\hline$\Delta \mathrm{G}^{\circ}(\mathrm{kJ} / \mathrm{mol})$ & -1.44 & -0.52 & -2.15 & -3.14 & -4.22 & -4.82 \\
\hline$\Delta \mathrm{H}^{\circ}(\mathrm{kJ} / \mathrm{mol})$ & -55.34 & & & & & \\
\hline$\Delta \mathrm{S}^{\circ}\left(\mathrm{Jmol}^{-1} \mathrm{~K}^{-1}\right)$ & -179.66 & & & & & \\
\hline \multicolumn{7}{|c|}{$\mathrm{PPy} / \mathrm{Ch}$} \\
\hline$\Delta \mathrm{G}^{\circ}(\mathrm{kJ} / \mathrm{mol})$ & -0.79 & -0.06 & -1.23 & -2.75 & -3.75 & -4.13 \\
\hline$\Delta \mathrm{H}^{\circ}(\mathrm{kJ} / \mathrm{mol})$ & -47.58 & & & & & \\
\hline$\Delta \mathrm{S}^{\circ}\left(\mathrm{Jmol}^{-1} \mathrm{~K}^{-1}\right)$ & -154.14 & & & & & \\
\hline \multicolumn{7}{|c|}{$\mathrm{PAn} / \mathrm{Ch}$} \\
\hline$\Delta \mathrm{G}^{\circ}(\mathrm{kJ} / \mathrm{mol})$ & -0.09 & -0.89 & -1.95 & -3.54 & -4.79 & -5.84 \\
\hline$\Delta \mathrm{H}^{\circ} \quad(\mathrm{kJ} / \mathrm{mol})$ & -53.30 & & & & & \\
\hline$\Delta \mathrm{S}^{\circ}\left(\mathrm{Jmol}^{-1} \mathrm{~K}^{-1}\right)$ & -175.09 & & & & & \\
\hline \multicolumn{7}{|c|}{$\mathbf{P P y} / \mathbf{S t}$} \\
\hline$\Delta \mathrm{G}^{\circ}(\mathrm{kJ} / \mathrm{mol})$ & -1.13 & -2.12 & -3.04 & -4.23 & -5.83 & -6.69 \\
\hline$\Delta \mathrm{H}^{\circ}(\mathrm{kJ} / \mathrm{mol})$ & -48.47 & & & & & \\
\hline$\Delta \mathrm{S}^{\circ}\left(\mathrm{Jmol}^{-1} \mathrm{~K}^{-1}\right)$ & -163.20 & & & & & \\
\hline
\end{tabular}

The expression for the intra-particle diffusion model can be written as:

$$
q_{t}=k_{p i} t^{1 / 2}+C_{i}
$$

Table 1 shows that the kinetic data obtained from batch biosorption experiments was a good fit for both pseudo first- and second-order kinetic models for all biosorbents.

\section{Biosorption Isotherms}

The linear equation of the Langmuir isotherm is:

$$
\frac{C_{e}}{q_{e}}=\frac{1}{q_{m} b}+\frac{C_{e}}{q_{m}}
$$

The linear expression for the Freundlichbiosorption isotherm is:

$$
\log q_{e}=\log K_{F}+\frac{1}{n} \log C_{e}
$$

The linear expression for the Temkinbiosorption isotherm is:

$$
q_{e}=B \ln A+B \ln C_{e}
$$

The linear equation of this model can be written as:

$$
\frac{1}{q e^{2}}=\left(\frac{B}{A}\right)-\left(\frac{1}{A}\right) \log C e
$$

The straight line equation for the (D-R) biosorption isotherm is:

$$
\ln q_{e}=\ln q_{m}-\beta \varepsilon^{2}
$$



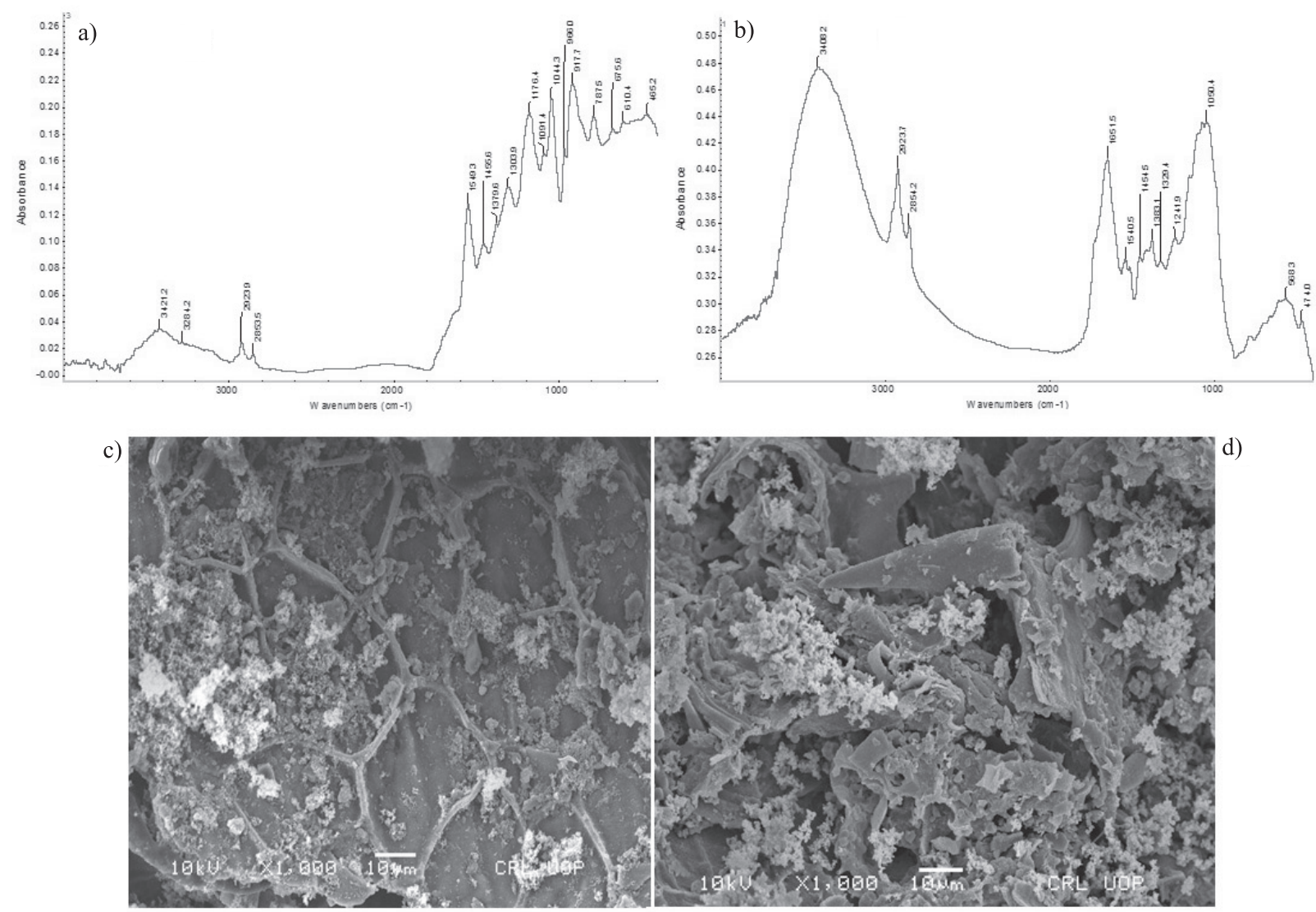

Fig. 2. (a, b) FITIR spectra (c, d) SEM images of loaded and dye unloaded biocomposites.

From Table 2 we observed that both the Langmuir and Freundlich biosorption isotherms showed satisfactory fitness on the equilibrium sorption data of AO-RL dye using all selected biosorbents. It showed the involvement of both chemical and physical processes in the sorption process due to the complex nature of biosorbents, but the much fitness among isotherms was found for the Freundlich biosorption isotherm, which indicated the greater involvement of physical phenomena. Thus it could be assumed that the sorption mechanism was electrostatic in nature.

\section{Thermodynamic Studies}

Thermodynamic study is very important for taking information about the nature of the biosorption process. The values of $\Delta \mathrm{G}^{\circ}$ were determined at different temperatures for acid dye by using the following equations:

$$
\begin{aligned}
& \Delta G^{\circ}=\Delta H^{\circ}-T \Delta S^{\circ} \\
& \Delta G^{\circ}=-R T \ln K_{d}
\end{aligned}
$$

The values of $\Delta \mathrm{H}^{\circ}$ and $\Delta \mathrm{S}^{\circ}$ for all acid dyes were determined from the values of slope and intercept by plotting the $\operatorname{lnK}_{d}$ vs $1 / T$ using the following Va'n $t$ hoff equation

$$
\ln \left(K_{d}\right)=\frac{\Delta \mathrm{S}^{\circ}}{R}-\frac{\Delta \mathrm{H}^{\circ}}{R} \times \frac{1}{T}
$$

The values of all thermodynamic parameters are listed in Table 3. The negative values of $\Delta \mathrm{H}^{\circ}$ for acid dye using the different types of selected biosorbents showed the exothermic nature of all biosorption processes for the removal of acid dye. The negative $\Delta \mathrm{S}^{\circ}$ values showed the reduction in disorder on solid and liquid interface during each biosorption process for the removal of acid dye using different types of selected biosorbents. The negative values of $\Delta \mathrm{G}^{\circ}$ indicated that the biosorption of acid dye using different types of biosorbents was spontaneous in nature.

\section{Characterization of Biosorbents}

The FT-IR study of different most-efficient biosorbents (PPy/RH) before and after the biosorption of acid dye was carried out in the $400-4,000 \mathrm{~cm}^{-1}$ range. The FT-IR spectra of PPy/RH before and after biosorption of AO-RL are represented in Figs 2(a-b). The FT-IR spectra of unloaded PPy/RH display the different types of bands that indicate the complex nature of biosorbents. The different bands appeared in the range of 3,054.5$3,421.2 \mathrm{~cm}^{-1}$ and showed the presence of $-\mathrm{NH}$ and bonded $-\mathrm{OH}$ functional groups, while the peaks that appeared in the $2,850.5-2,925.5 \mathrm{~cm}^{-1}$ range revealed the existence 

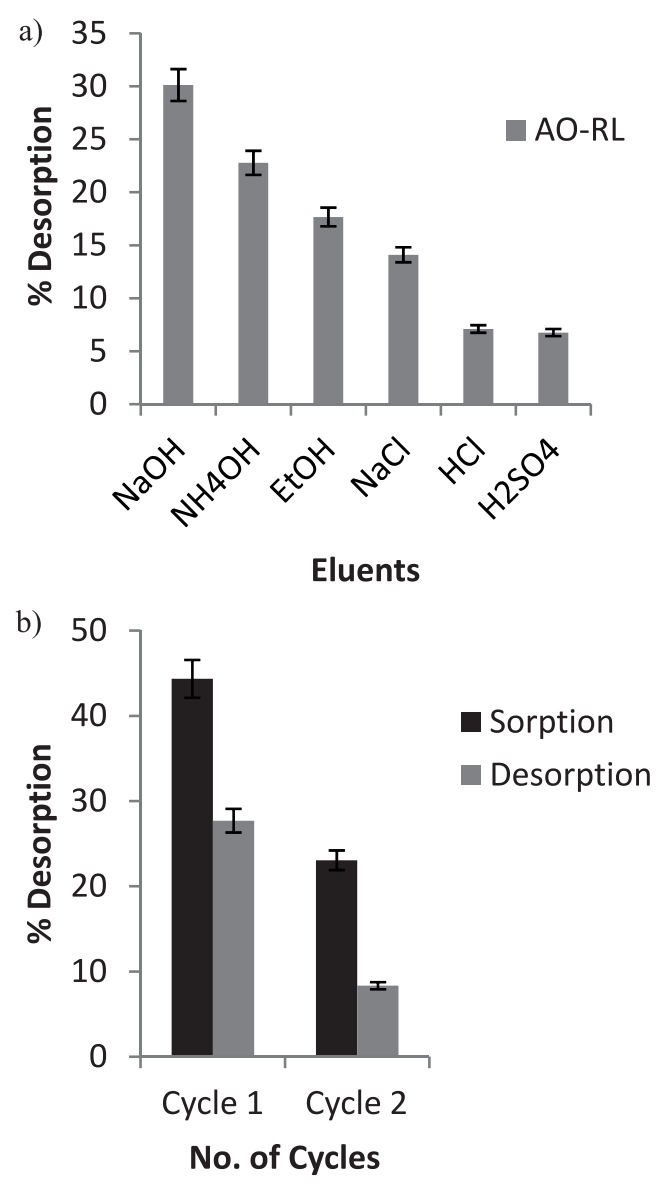

Fig. 3. Regeneration study: a) desorption, b) recycling.

of $\mathrm{C}-\mathrm{H}$ stretching of methyl and methylene groups. The bands observed at 1,651.6-1,736.6 $\mathrm{cm}^{-1}$ indicated the existence of $\mathrm{C}=\mathrm{O}$ stretching of non-ionized carboxylate group of carboxylic acids and the $\mathrm{C}=\mathrm{O}$ stretching of carboxylic acid with hydrogen bond. The bands seen at 1,549.3-1,579.6 $\mathrm{cm}^{-1}$ indicated the presence of a secondary amine functional group. The loaded spectra showed the disappearance of bands that existed in the 3,054.5-3,421.2 $\mathrm{cm}^{-1}$ range and appearance of the bands at 3,406.8-3,416.0 $\mathrm{cm}^{-1}$ range with significantly high absorbance value. This indicated the active participation of $-\mathrm{NH}_{2}$ and $-\mathrm{OH}$ groups in binding of sorbate molecules with sorbent surface. Absorbance of spectral peaks in the 2,850.5-2,925.5 $\mathrm{cm}^{-1}$ range were enhanced in dye-loaded spectra, which revealed the involvement of these functional groups in binding of dye and the shifting of peaks that were displayed in 1,651.6-1,736.6 $\mathrm{cm}^{-1}$ and 1,549.3-1,579.6 $\mathrm{cm}^{-1}$ range toward the higher absorbance attributed the participation of $\mathrm{C}=\mathrm{O}$ and secondary amine functional groups in binding of dye anions. Thus, the FT-IR spectra helped the identification of active functional groups that were responsible for the sorption of dye anions [13, 24].

The morphology and features of biosorbent surface can be investigated with the help of a scanning electron microscope (SEM), which can be utilized to find out the porous structure of biosorbent and also give information about particle shape or size. The SEM images of unloaded and loaded biosorbents are shown in Figs 2(c-d). The SEM images showed that the texture of biosorbents was porous and fibrous in nature, containing high heterogeneity that contributed to dye biosorption. On the basis of these findings it can be concluded the biocomposites are efficient adsorbents, and to avoid environmental pollution [34-42] biocomposites can be used to adsorb pollutants from wastewater.

\section{Conclusions}

The present study was carried to evaluate the dye adsorption capacity of biocomposites as cost-effective, efficient, and environmentally friendly materials. The prepared biocomposites were employed for the adsorption of dye, and process variables were optimized for maximum dye adsorption. Results revealed that the efficiency of polymeric biocomposites was good for the removal of acid dye from textile effluents. The adsorption capacities revealed that biocomposites are efficient adsorbents and could possibly be used for the adsorption of dyes from textile wastewater.

\section{Regeneration Study}

The recycling study helps to recover the sorbent and sorbate and reusability of sorbent is necessary for its application on practical scale wastewater treatment. The selection of an appropriate eluent is an important task. In the present study, desorption of selected acid dye from the most efficient biosorbent $(\mathrm{PPy} / \mathrm{RH})$ was carried out using $0.05 \mathrm{~N}$ of different eluents $\left(\mathrm{NaOH}, \mathrm{NH}_{4} \mathrm{OH}, \mathrm{EtOH}, \mathrm{NaCl}\right.$, $\mathrm{HCl}$, and $\left.\mathrm{H}_{2} \mathrm{SO}_{4}\right)$. The maximum percentage desorption (30.12\%) of AO-RL dye was obtained using $0.05 \mathrm{~N} \mathrm{NaOH}$. The results are represented in Figs 3(a-b). The number of sorption/desorption cycles of AO-RL were studied using $0.05 \mathrm{~N} \mathrm{NaOH}$ solution. It was determined that the PPy/RH could be utilized efficiently up to two cycles.

\section{Acknowledgements}

This work is part of the Ph.D. thesis of Saima Noreen. The authors are thankful to the Higher Education Commission (HEC) of Pakistan for financial assistance under the Indigenous Ph.D. Fellowship Program.

\section{References}

1. QURESHI K., AHMAD M., BHATTI I., IQBAL M., KHAN A., Cytotoxicity reduction of wastewater treated by advanced oxidation process. Chem. Int. 1, 53, 2015.

2. SAYED M., Efficient removal of phenol from aqueous solution by the pulsed high-voltage discharge process in the presence of $\mathrm{H}_{2} \mathrm{O}_{2}$. Chem. Int. 1, 81, 2015.

3. SHINDY H., 2016. Basics in colors, dyes and pigments chemistry: A review. Chem. Int. 2, 29, 2016. 
4. SHINDY H., GOMA M., HARB N., Novel carbocyanine and bis carbocyanine dyes: synthesis, visible spectra studies, solvatochromism and halochromism. Chem. Int. 2, 222, 2016.

5. STIRKE A., APETREI R.M., KIRSNYTE M., DEDELAITE L., BONDARENKA V., JASULAITIENE V., PUCETAITE M., SELSKIS A., CARAC G., BAHRIM. G. Synthesis of polypyrrole microspheres by Streptomyces spp. Polymer. 99, 84, 2016.

6. BABARINDE A., OGUNDIPE K., SANGOSANYA K.T., AKINTOLA B.D., ELIZABETH HASSAN A.-O., Comparative study on the biosorption of $\mathrm{Pb}$ (II), $\mathrm{Cd}$ (II) and $\mathrm{Zn}(\mathrm{II})$ using Lemon grass (Cymbopogon citratus): kinetics, isotherms and thermodynamics. Chem. Int. 2, 89, 2016.

7. BABARINDE A., ONYIAOCHA G.O., Equilibrium sorption of divalent metal ions onto groundnut (Arachis hypogaea) shell: kinetics, isotherm and thermodynamics. Chem. Int. 2, 37, 2016.

8. IQBAL M., KHERA R.A., Adsorption of copper and lead in single and binary metal system onto Fumaria indica biomass. Chem. Int. 1, 157b, 2015.

9. NOREEN S., BHATTI H.N., NAUSHEEN S., ZAHID M., ASIM. S. Biosorption of Drimarine Blue HF-RL using raw, pretreated, and immobilized peanut hulls. Desalin. Water Treat. 52, 7339, 2014.

10. NOREEN S., BHATTI. H.N. Fitting of equilibrium and kinetic data for the removal of Novacron Orange P-2R by sugarcane bagasse. J. Ind. Eng. Chem. 20, 1684, 2014.

11. ANSARI R., DEZHAMPANAH. H. Application of polyaniline/sawdust composite for removal of Acid Green 25 from aqueous solutions: Kinetics and thermodynamic studies. Eur. Chem. Bull. 2, 220, 2013.

12. RASHID A., BHATTI H.N., IQBAL M., NOREEN S., Fungal biomass composite with bentonite efficiency for nickel and zinc adsorption: a mechanistic study. Ecol. Eng. 91, 459, 2016.

13. SHOUKAT S., BHATTI H.N., IQBAL M., NOREEN S. Mango stone biocomposite preparation and application for crystal violet adsorption: A mechanistic study. Micropor. Mesopor. Mater. 239, 180, 2017.

14. ANSARI R. Application of polyaniline and its composites for adsorption/recovery of chromium (vi) from aqueous solutions. Acta Chim. Slov. 53, 88, 2006.

15. PALANISAMY P.N., AGALYA A., SIVAKUMAR. P. Polymer composite - A potential biomaterial for the removal of reactive dye. Electron. J. Chem. 9, 1823, 2012.

16. JANAKI V., OH B.T., SHANTHI K., LEE K.J., RAMASAMY A., KAMALA-KANNAN. S. Polyaniline/ chitosan composite: An eco-friendly polymer for enhanced removal of dyes from aqueous solution. Synth. Met. 162, 974, 2012.

17. KARTHIKEYAN M., KUMAR K.S., ELANGO. K. Batch sorption studies on the removal of fluoride ions from water using eco-friendly conducting polymer/bio-polymer composites. Desalination. 267, 49, 2011.

18. JANAKI V., VIJAYARAGHAVAN K., OH B.T., LEE K. J., MUTHUCHELIAN K., RAMASAMY A., KAMALAKANNAN. S. Starch/polyaniline nanocomposite for enhanced removal of reactive dyes from synthetic effluent. Carbohyd. Poly. 90, 1437, 2012.

19. ANSARI R., MOSAYEBZADEH Z. Removal of eosin y, an anionic dye, from aqueous solutions using conducting electroactive polymers. Iran. Poly. J. 19, 541, 2010.

20. HEIBATI B., RODRIGUEZ-COUTO S., AL-GHOUTI M.A., ASIF M., TYAGI I., AGARWAL S., GUPTA V.K.
Kinetics and thermodynamics of enhanced adsorption of the dye ar 18 using activated carbons prepared from walnut and poplar woods. J. Mol. Liq. 208, 99, 2015.

21. BASERI J.R., PALANISAMY P.N., SIVAKUMA R.P. Application of polyanilinenano composite for the adsorption of acid dye from aqueous solutions. Electron. J. Chem. 9, 1266, 2012.

22. SADAF S., BHATTI. H.N. Batch and fixed bed column studies for the removal of indosol yellow bg dye by peanut husk. J. Taiwan. Inst. Chem. Eng. 45, 541, 2014.

23. AHMED S.M., EL-DIB F.I., EL-GENDY N.S., SAYED W.M., EL-KHODARY. M. A kinetic study for the removal of anionic sulphonated dye from aqueous solution using nano polyaniline and baker's yeast. Arabian J. Chem. 9, S1721, 2012.

24. TAHIR M.A., BHATTI H.N., IQBAL M. Solar red and brittle blue direct dyes adsorption onto eucalyptus angophoroides bark: Equilibrium, kinetics and thermodynamic studies. J. Environ. Chem. Eng. 4, 2431, 2016.

25. BANIMAHD KEIVANI M., ZARE K., AGHAIE H., ANSARI. R. Removal of methylene blue dye by application of polyaniline nano composite from aqueous solutions. J. Phys. Theoret. Chem. 6, 63, 2009.

26. TAYEBI H.A. Synthesis of polyaniline/nanosilica nanocomposite for removal of reactive orange 16 from aqueous solutions. Iran. J. Org. Chem. 8, 1737, 2016.

27. FAYOUD N., TAHIRI S., ALAMI YOUNSSI S., ALBIZANE A., GALLART-MATEU D., CERVERAM., DE LA GUARDIA. M. Kinetic, isotherm and thermodynamic studies of the adsorption of methylene blue dye onto agrobased cellulosic materials. Desalin. Water Treat. 57, 16611, 2016.

28. SADAF S., BHATTI H.N., ALI S., REHMAN. K.U. Removal of indosol turquoise FBL dye from aqueous solution by bagasse, a low cost agricultural waste: Batch and column study. Desalin. Water Treat. 52, 184, 2014.

29. ESMAELI A., JOKAR M., KOUSHA M., DANESHVAR E., ZILOUEI H., KARIMI. K. Acidic dye wastewater treatment onto a marine macroalga, nizamuddina zanardini (phylum: Ochrophyta). Chem. Eng. J. 217, 329, 2013.

30. ASGHER M., BHATTI. H.N. Removal of reactive blue 19 and reactive blue 49 textile dyes by citrus waste biomass from aqueous solution: Equilibrium and kinetic study. Can. J. Chem. Eng. 90, 412, 2012.

31. AKAR T., OZCAN A.S., TUNALI S., OZCAN. A. Biosorption of a textile dye (acid blue 40) by cone biomass of thuja orientalis: Estimation of equilibrium, thermodynamic and kinetic parameters. Bioresour. Technol. 99, 3057, 2008

32. ABBAS A., MURTAZA S., SHAHID K., MUNIR M., AYUB R., AKBER. S. Comparative study of adsorptive removal of congo red and brilliant green dyes from water using peanut shell. Middle-East J. Sci. Res. 11, 828, 2012.

33. HO Y., MCKAY G., WASE D., FORSTER C. Study of the sorption of divalent metal ions on to peat. Adsorpt. Sci. Technol. 18, 639, 2000.

34. JAFARINEJAD S. Control and treatment of sulfur compounds specially sulfur oxides ( $\mathrm{SOx}$ ) emissions from the petroleum industry: a review. Chem. Int. 2, 242, 2016.

35. JAMAL M.A., MUNEER M., IQBAL M. Photo-degradation of monoazo dye blue 13 using advanced oxidation process. Chem. Int. 1, 12, 2015.

36. MAJOLAGBE A.O., ADEYI A.A., OSIBANJO O. Vulnerability assessment of groundwater pollution in the vicinity of an active dumpsite (Olusosun), Lagos, Nigeria. Chem. Int. 2, 232, 2016. 
37. NGOBIRI N., OKOROSAYE-ORUBITE K. Adsorption and corrosion inhibition characteristics of two medicinal molecules. Chem. Int. 3, 185, 2017.

38. PETER U.C., CHINEDU U. Model prediction for constant area, variable pressure drop in orifice plate characteristics in flow system. Chem. Int. 2, 80, 2016.

39. UKPAKA C. BTX Degradation: The concept of microbial integration. Chem. Int. 3, 8, 2016.
40. UKPAKA C. Development of model for bioremediation of crude oil using moringa extract. Chem. Int. 2, 19, 2016.

41. UKPAKA C. Empirical model approach for the evaluation of $\mathrm{pH}$ and conductivity on pollutant diffusion in soil environment. Chem. Int. 2, 267, 2016.

42. UKPAKA C. Predictive model on the effect of restrictor on transfer function parameters on pneumatic control system. Chem. Int. 2, 128, 2016. 